Egyptian Journal of Rabbit Science, 27 (2): 325- 338(2017)

\title{
IMPACT OF DIETARY SUPPLEMENTATION with MORINGA (Moringa oleifera) ON PRODUCTIVE PERFORMANCE, PHYSIOLOGICAL RESPONSE AND IMMUNITY OF GROWING RABBITS
}

\author{
Y.K. Badawi ; El-Sawy, M.A. and Nehad, A. Ramadan \\ Anim. Prod. Res. Inst., Agric. Res. Cent., Min. of Agric., Dokki, Giza, Egypt \\ E.mail: elsawy1966@Gmail.com
}

Forty five growing New Zealand White (NZW) rabbits aged five weeks and weighed in average $784.7 \pm 16.65 \mathrm{gm}$ were randomly distributed by weight into five treatment groups (9 rabbits each), the experiment lasted 35 days. The $1^{\text {st }}$ group fed a basal diet free from Moringa Olifera Leaf Meal (MOLM) and served as control. The $2^{\text {nd }}$, $3^{\text {rd }}, 4^{\text {th }}$ and $5^{\text {th }}$ groups were fed the same basal diet supplemented with dried MOLM at levels of 0.1, 0.2, 0.3 and 0.4\%, respectively.

The results showed that: final live body weight and daily body weight gain were lower $(P \leq 0.05)$ in rabbits fed different levels of MOLM compared with the control. Feed conversion ratio (FCR) was the best $(P \leq 0.05)$ with rabbits fed 0.3\% MOLM compared with the control and other groups. The FCR recorded 2.95; 3.17; 2.98; 2.83 and 3.24 for rabbits fed diet supplemented with $0.0 ; 0.1 ; 0.2 ; 0.3$ and $0.4 \%$ MOLM, respectively.

The mortality rate (\%) recorded zero\% in all experimental groups, meaning that supplementation of different levels of MOLM up to $0.4 \%$ of the formulated diet had no adverse effects on the rabbits health.

The levels of blood serum total protein, albumin and globulin were within the normal physiological range in all rabbit groups, whereas lysozyme levels were significantly $(P \leq 0.01)$ higher in rabbit groups fed diets supplemented with moringa and positively correlated with the level of moringa leaves in the diet. Moringa oleifera leaves meal could be added up to $0.4 \%$ in the diet of growing rabbits to improve their immunity response and health status.

Another experiment with using large number of rabbits and higher levels of MOLM should be carried out to ascertain the actual effects of feeding moringa leaves on immunity response and health status of rabbits.

Key words: Moringa oleifera leaves meal, rabbits, growth, immunity, blood serum proteins, lysozyme. 
Moringa Oleifera is a perennial plant, commonly known as "The Miracle tree or Horseradish tree" and is considered the most widely distributed species of Moringaceae family. Moringa plant has many of medicinal, industerial and agricultural uses. The leaves are highly nutritional and contain significant quantities of vitamins (A, B complex and C), minerals (calcium, potassium, phosphorus and iron) and high quality protein (Chen et al., 2009). Moringa leaves are free from the toxic metals such as mercury, arsenic and cadmiumand antinutritive substances ,making the possibility of incorporation it into the poultry and animal diets without adverse effects on production and health status (Frederick, 2010 and Dougnon et al, 2012). Moringa leaves contain high levels of vitamin $\mathrm{C}$ and E, carotenoids, flavonoids and selenium, make it potential as antioxidant (Moyo et al., 2012).

Inclusion of MOLM in the diet of quail have been improved the quality of quail meat products in the pre-slaughter or post-slaughter stages (Valeria and Williams, 2011). The author interpreted this improvement to the antioxidants compounds present in MOLM. Moringa leaves contain antibacterial and antifungal compounds, thus reduce the activity of pathogenic bacteria and moulds and improves the digestibility and feed utilization of ingested feeds by chickens (Gaia, 2005).

Moringa leaves possess antitumor, anti-inflammatory, antiulcer, antispasmodic, diuretic, antihypertensive, cholesterol lowering, antioxidant, antidiabetic and hepatoprotective activities (Ritu et al., 2011).

Moreover, it was reported that Moringa oleifera leaves effectively prevent the morphological changes and oxidative damage in human and animals by enhancing the activities of antioxidant enzymes, reducing the intensity of lipid peroxidation and inhibiting generation of free radicals (Guevara et al., 1999). Moringa leaves are also used to promote the immune system against infections (Anwar et al., 2007) and its extracts have positive effects on hematological parameters of rabbits (Caceres et al., 1992).

This study aimed to verify the nutritional impact of feeding different levels of MOLM in the diet on some productive and physiological performance traits and immunity response in rabbits.

\section{MATERIALS AND METHODS}

Moringa leaves were obtained from Egyptian Scientific Association of Moringa, National Research Center. The fresh leaves were harvested, air-dried under shadow until the moisture of collected leaves reached $10 \%$. The dry 
leaves were finally milled, sieved $(1 \mathrm{~mm}$ mesh) and stored in a well tight polyethylene bags at room temperature $25^{\circ} \mathrm{C}$.

Forty five unsexed growing New Zealand White (NZW) rabbits aged five weeks old with an average body weight of $784.7 \pm 16.65 \mathrm{gm}$ were randomly distributed by weight into five experimental groups ( 9 rabbits in each) and lasted 35 days. The rabbits were housed individually in galvanized metal wire cages equipped with feeding and water troughs, where the first group of rabbits was given a basal pelleted diet free from MOLM and served as control.

The basal diet (Table 1) was formulated to contain: $16.72 \%$ crude protein, $2.95 \%$ crude fat, $13.07 \%$ crude fiber and $2490 \mathrm{kcal} / \mathrm{kg}$ feed as DE. The $2^{\frac{n d}{}}, 3^{\text {rd }}, 4^{\text {th }}$ and $5^{\text {th }}$ groups were given the same basal diet supplemented with MOLM at levels of $0.1,0.2,0.3$ and $0.4 \%$, respectively.

Initial and final live body weight (IBW and FBW), daily feed intake (DFI), daily body weight gain (DBWG), daily feed conversion ratio (FCR) and mortality rate $\%$ were recorded. At 70 days of age, blood samples were taken randomly into dried and cleaned tubes from three rabbits in each group from the ear vein. Blood samples were centrifuged at 3000 r.p.m. for $20 \mathrm{~min}$ to separate blood serum. Blood serum samples were subjected to biochemical analysis for determination of total protein (Sonnerwirth and Jarrett, 1980), albumin (Doumas et al., 1971), and globulin was calculated by difference.

Zinc sulphate turbidity test was used to gain a rough estimation of the amount of immunoglobulins present in the serum. A small amount of serum was added to a zinc sulfate solution and allowed to incubate at room temperature for $1 \mathrm{~h}$. Zinc sulfate will cause precipitation of the immunoglobulins, which makes the solution cloudy instead of clear. A lack of cloudiness indicates a lack of immunoglobulins (Johnson et al., 1995). The turbidity is expressed as ZST units, which in turn indicate the amount of immunoglobulin present in the sample. Blood lysozymes level, a parameter of non-specific immunity was determined according to the established procedure of Amadori et al., (1997).

\section{Statistical analysis:}

Data were analyzed using the General Linear Model (GLM) procedure of SAS (2004) as following model:

$$
\mathrm{Y}_{\mathrm{ijk}}=\mu+\mathrm{T}_{\mathrm{i}}+\mathrm{e}_{\mathrm{ijk}}
$$

Where: $Y_{i j k}=$ An observation; $\mu=$ Overall mean; $T_{i}=$ Moringa level; and $\mathrm{e}_{\mathrm{ijk}}=$ Experimental error.

The significant differences among means were tested by using Duncan's Multiple Rang Test (Duncan, 1955). 
Table 1. The ingredients and chemical composition of the pelleted diet fed to rabbits during the experimental period

\begin{tabular}{|l|c|}
\hline \multicolumn{1}{|c|}{ Ingredients } & \% \\
\hline Clover hay & 30.00 \\
Wheat bran & 26.38 \\
Barley grain & 23.00 \\
Soybean meal (44\% CP) & 16.00 \\
Molasses & 3.00 \\
Lime stone & 1.00 \\
Sodium chloride & 0.50 \\
Vitamins \& Mineral Premix * & 0.30 \\
Moringa *** & ---- \\
\hline Total & $\mathbf{1 0 0 . 0 0}$ \\
\hline & \\
Calculated chemical composition ** & 16.72 \\
Crude protein (CP)\% & 2.95 \\
Ether extract (EE)\% & 13.07 \\
Crude fiber (CF)\% & 2490.00 \\
Digestible energy (Kcal/Kg diet) & \\
\hline
\end{tabular}

* Each one kg of Premix contains: $150000 \mathrm{IU}$ of Vit. A, ,100 mg Vit. E, $21 \mathrm{mg}$ Vit. K3, $10 \mathrm{mg}$ Vit. $B_{1}, 40 \mathrm{mg}$ Vit. B2, $15 \mathrm{mg}$ Vit. $\mathrm{B}_{6}, 0.1 \mathrm{mg}$ Vit. $\mathrm{B}_{12}, 200 \mathrm{mg}$ Niacin, $100 \mathrm{mg}$ Pantothenic acid, $0.5 \mathrm{mg}$ Biotin, $10 \mathrm{mg}$ Folic acid, $5000 \mathrm{mg}$ Choline chloride, $450 \mathrm{mg}$ $\mathrm{Zn}, 600 \mathrm{mg} \mathrm{Mn}, 0.3 \mathrm{mg} \mathrm{Fe}, 50 \mathrm{mg} \mathrm{Cu}, 0.25 \mathrm{~g} \mathrm{I}, 1 \mathrm{mg} \mathrm{Se}$.

** Digestible energy calculated according to NRC (1977).

*** Moringa oleifera leaves meal were added to the basal diet at levels of $0.1,0.2,0.3$ and $0.4 \%$, respectively.

\section{RESULTS}

\section{Productive performance:}

Results of final live body weight (FBW), daily body weight gain (DBWG), daily feed intake (DFI) and daily feed conversion ratio (FCR) for the experimental period are presented in Table 2.

Final body weights and average daily weight gain were significantly $(\mathrm{P} \leq 0.05)$ lower in rabbit groups fed different levels of MOLM compared with those of the control. The FBW recorded 2033.70, 1826.24, 1896.16, 1925.91 and $1929.79 \mathrm{gm}$ for rabbits fed diet supplemented with 0.0, 0.1, $0.2,0.3$ and $0.4 \%$ MOLM, respectively. 
Daily feed intake had no obvious trend for growing rabbits fed diet supplemented with different levels of MOLM, however it was the highest for rabbits fed $0.4 \%$ MOLM and the lowest with those fed $0.3 \%$ MOLM compared with the other groups.

Average FCR at the end of the experiment were 2.95, 3.17, 2.98, 2.83 and 3.24 for those fed diet supplemented with $0.0,0.1,0.2,0.3$ and $0.4 \%$ MOLM, respectively, indicating that feed conversion ratio was improved with rabbits fed diet supplemented with $0.3 \%$ moringa compared to the other groups. Mortality rate recorded zero for all groups through the experimental period.

\section{Blood analysis:}

Table 3 and Figure 2 show that blood serum total protein levels for growing rabbits were not affected significantly by feeding the different levels of MOLM. Total serum protein values were 5.66, 5.94, 5.49, 6.73 and $6.39 \mathrm{~g} / \mathrm{dl}$ for those fed $0.0,0.1,0.2,0.3$ and $0.4 \%$ MOLM, respectively.

Albumin levels were increased as MOLM level increased, except for those fed $0.2 \%$ MOLM diet. The values of albumin were $1.57,1.79,1.60$, 2.78 and 2.22 for rabbits fed diet supplemented with $0.0,0.1,0.2,0.3$ and $0.4 \%$ moringa, respectively (Table 2 and Figure 1).

No obvious trend was detected for the effect of treatments on blood serum globulin levels. However, feeding 0.3\% MOLM diet significantly $(\mathrm{P} \leq 0.05)$ elevated the level of globulin in the blood serum compared to the control and the other treatment groups (Table 2 and Figure 1).

Lysozymes levels in growing rabbits were significantly $(\mathrm{P} \leq 0.05)$ increased by increasing the level of MOLM supplementation in the diet. The lysozymes levels were $6.33,61.20,259.66,300.00$ and $213.50 \mu \mathrm{g} / \mathrm{ml}$ for rabbits fed $0.0,0.1,0.2,0.3$ and $0.4 \%$ MOLM, respectively.

\section{DISCUSSION}

Results are in agreement with the findings of Yassmine et al., (2017) who found that significant decrease in daily feed intake with an increase of MOLM up to $0.2 \%$. They also, showed that inclusion of MOLM improves the FCR compared with control group, but this improvement didn't significant. The daily feed intake and the FCR values were similarly improved with increasing level of MOLM, but the differences were not statistically significant (Frederick, 2010). The FCR ratio obtained in this study were nearly of those (2.63-4.00) reported by earlier researchers in the tropics (Ayers et al., 1996; Okorie, 2003); but were lower than that of 5.32 - 5.63 reported by Eustace 
BADAWI et al. 

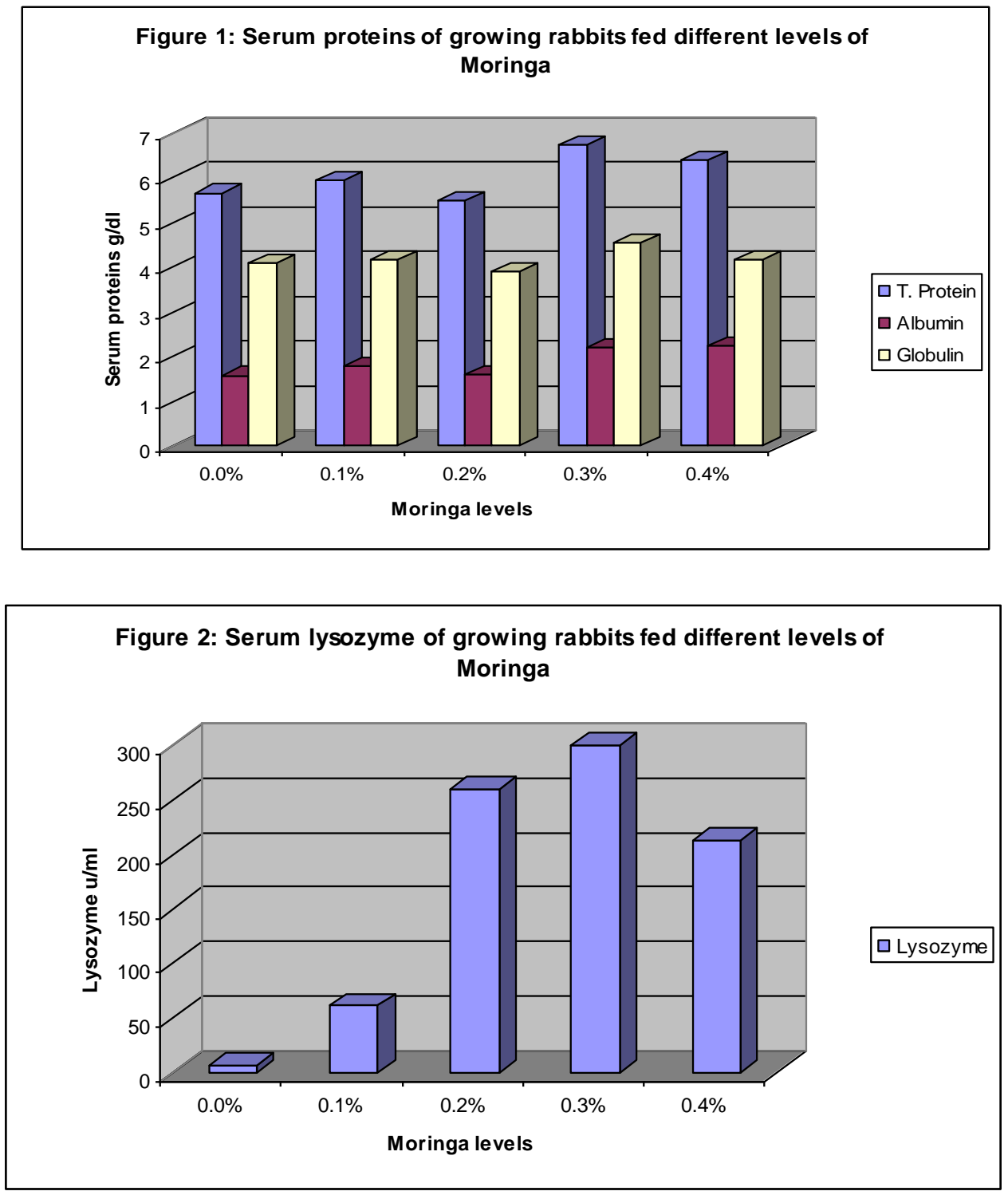
et al. (2003). The generally poor FCR ratio obtained were probably due to the relatively low growth rates.

On the other hand, results are in disagreement with the findings of ElBadawi et al., (2014) who found that supplementation of Moringa olifera dry leaves to growing rabbits diets at 0.15 or $0.30 \%$ improved protein utilization efficiency and Bouatene et al., (2011) who found that average body weight, body weight gain, growth rate and feed efficiency were the best $(\mathrm{P} \leq 0.05)$ in rabbits supplemented in the diet with MOLM at levels of 1.5 or $3 \%$ compared with control group. Also, Dougnon et al., (2012) who found that the best weight gain and feed conversion ratio were obtained in rabbits fed pellets of MOLM as a substitute for 10 and $15 \%$ of pelleted commercial ration. Feed conversion ratio recorded 4.24 and 4.02 for rabbits fed 10 and 15\% MOLM, respectively. The rabbit's carcass yield ranged from 60.6 to $64.5 \%$. Pellets of $M$. Oleifera can substitute the commercial feed at a level of $15 \%$ with a positive effect on weight gains and carcass characteristics of rabbits. Yassmine et al., (2017) found that rabbit's final body weight was increased significantly by MOLM supplementation in the diet at 0.2 and $0.3 \%$ compared with control group.

Concerning blood analysis, results are in agreement with those reported by Frederick (2010) who found that feeding rabbit's levels of 5, 10, 15 or $20 \%$ moringa leaves meal (MOLM) to substitute soybean meal in diet did not alter the blood hematological and biochemical characteristics such as total protein, albumin and globulin. Yassmine et al., (2017) found that hemoglobin was not significantly affected by different levels of MOLM.

Concerning immunity, Olugbemi et al., (2010) reported that Moringa oleifera leaves had a beneficial effect on the immune responses and improve intestinal health of broilers. Moringa oleifera leaves are widely used for its antimicrobial activity (Suarez et al., 2005) and its pharmacological properties (Mehta et al., 2003). It also contain sufficient quantities of carotene, ascorbic acid, iron, methionine and cystine (Makkar and Becker, 1996). Yassmine et al., (2017) found significant increase in WBCs values in the rabbit groups fed diets containing MOLM compared with the control group. High counts of WBCs enhance adaptability to local environment and disease prevalent condition (Soetan et al., 2013). Yassmine et al., (2017) showed that MOLM was immunomodulatory, it stimulated numerically IgG and significantly IgM immune response of growing rabbits. Sudha et al., (2010) showed that methanol extract of moringa leaves given orally to mice at doses of 250 and $750 \mathrm{mg} / \mathrm{kg}$ stimulated both cellular and humoral immune responses.

Moscati et al., (2008) reported that lysozyme at level of $27.19 \mu \mathrm{g} / \mathrm{ml}$ is a strong antibacterial enzyme (against Gram positive) and has a synergic 
action with immune humeral response, and factors of the serum complement. Moscati, et al., (2008) recorded that lysozyme value of 27.19 $\mu \mathrm{g} / \mathrm{ml}$ as an innate immunity indicator was higher than those reported by Carroll and Martinez, (1979) in healthy rabbits $(0.85 \mu \mathrm{g} / \mathrm{ml})$. Moscati et al., (2005) reported values of rabbit serum lysozyme from 4.8 to $11.0 \mu \mathrm{g} / \mathrm{ml}$. Innate immunity plays an important role in preventing infection as a firstline defense and also contributes antigen presenting cells that activate the adaptive immune response, which is specific and powerful (Tizard, 2013).

The positive relationship between lysozymes levels and MOLM supplemented diets confirming the potential effect of moringa on improving the immune response and diseases resistance in rabbits. This is might be due to the presence of considerable levels of antioxidants (Vit. E and C, carotenoids and selenium) in MOLM which enhance the release of lysozymes (Klasing and Leshchincky 2000 and Gallois et al., 2005). Recently, Dabbou et al., (2016) found that lysozyme and the complement system are interesting indicators of how innate immunity functions. They reported that their work has been performed in a standard environment without infection, stress or other factors that could influence immune responses. Therefore, it is difficult that experiments conducted in normal conditions could result in a significant effect on immunity, despite supplementation with an immunomodulating agent. In this study it could be concluded that supplementation of Moringa oleifera Leaf Meal MOLM in the growing rabbits diet had a significant effect on rabbit physiological responses and immunity. Humeral and innate immunity act by releasing high amount of lysozyme and increase of albumin ratio.

Conclusively, from these results it could be concluded that moringa supplementation might play a role as immunity enhancer and diseases resistance for growing rabbits. Moringa oleifera leaves meal could be added up to $0.4 \%$ in the diet of growing rabbits to improve their immunity response and health status.

Another experiment with using large number of rabbits and higher levels of MOLM should be carried out to ascertain the actual effects of feeding moringa leaves on growth performance, immunity response and health status of rabbits.

\section{ACKNOWLEDGEMENT}

The authors are thankful to Prof. Dr. Aboelfotoh Mohammed Abdallah Chief of Egyptian Scientific Association of Moringa, National Research Center for providing Moringa Leave Powder to carry out this work. 


\section{REFFERENCES}

Amadori M., Archetti I.L., Frassinelli M., Bagni M., Olzi E., Caronna G., and Lanterni M. (1997). An immunological approach to the evaluation of welfare in Holstein Frisian cattle. J. Vet. Med. B., 44: 321-327.

Anwar F., Latif S., Ashraf M., and Gilani A.H. (2007). Moringa oleifera: a food plant with multiple medicinal uses. Phytother Res., 21: 17-25.

Ayers, A.C., Barrett, R.P. and Cheeke P.R. (1996). Feeding value of tree leaves (Hybrid Poplar and black locust) evaluated with sheep, goats and rabbits. Animal Feed Science Technology, 57: 51-52.

Bouatene Djakalia, Bohoua Louis Guichard and Dabonne Soumaila (2011). Effect of Moringa oleifera on growth performance and healthy status of young post-weaning rabbits. Res. J. Poult. Sci., 4(1): 7-13.

Caceres A., Saravia A., Rizzo S., Zabala L., De Leon E. and Nave F. (1992). Pharmacological properties of Moringa oleifera. 2: Screening for anti-spasmodic, anti-inflammatory and diuretic activity. $J$. Ethnopharmacol., 36: 233-237.

Carroll S.F. and Martinez R.J. (1979). Role of rabbit lysozyme in in vitro serum and plasma serum bactericidal reactions against Bacillus subtilis. Infect. Immun., 25: 810-819.

Chen P.Y., Kuo Y.C., Chen C.H., Kuo Y.H. and Lee CK. (2009). Isolation and mmunomodulatory effect of homoisoflavones and flavones from Agave sisalana Perrine ex Engelm. Molecules, 14: 1789-1795.

Dabbou S., L. Rotolo, A. Kovitvadhi, S. Bergagna, D. Dezzutto, R. Barbero, P. Rubiolo, A. Schiavone, M. De Marco, A. N. Helal, I. Zoccarato and L. Gasco (2016). Rabbit dietary supplementation with pale purple coneflower. 1. Effects on the reproductive performance and immune parameters of does. Animal, 10:7, pp 1101-1109.

Dougnon, T. J., Aboh, B. A, Kpodékon, T. M., Honvou, S. and Youssao, I. (2012). Effects of substitution of pellet of Moringa oleifera to commercial feed on rabbit's digestion, growth performance and carcass trait. Journal of Applied Pharmaceutical Science, Vol. 2 (9), pp. 15-19.

Doumas, B.T., Watson, W.A. and Biggs H.C. (1971). Albumin standards and Management of serum albumin with bromocresol green. Chin. Chim. Acta. , 31:87-96.

Duncan, D. B. (1955). Multiple Range and Multiple F-test. Biometrics, 11: $1-42$. 
El-Badawi, A. Y.; Omer, H. A. A.; Abedo, A. A. and Yacout, M. H. M. (2014). Response of Growing New Zealand White Rabbits to Rations Supplemented with Different Levels of Moringa oleifera Dry Leaves. Global Veterinarian, 12 (4): 573-582.

Eustace, A., Iyayi, O., Oluwakemi, O. and Odueso, M. (2003). Response of some metabolic and biochemical indices in rabbits fed varying levels of dietary cyanide. African Journal of Biomedical Research, 6(1): 43-47.

Frederick, N. (2010). Effect of moringa leaf meal on nutrient digestibility, growth, carcass and blood indices of weaned rabbits. Master of Science Thesis, Faculty of Agriculture and Natural Resources, Kwame Nkrumah University of Science and Technology, Kumasi.

Gaia, S. (2005). Wonder tree 100 facts moringa fact 04 exceptional animal feed moringa as livestock feed \& pet food. Moringa Mission Trust. Available at: http:// gaiatheliving planet .blogspot.com/ 2005 /06/ wonder tree -100-facts- moringa -fact-04. ht MOLM.

Gallois M., Gidenne T., Forthun-Lamothe L., Le Huerou-Luron I and Lallès J.P. (2005). An early stimulation of solid feed intake slightly influences the morphological gut maturation in the rabbit. Reprod. Nutr. Dev., 45: 109-122.

Guevara A.P., Vargas C. and Sakurai H. (1999). An antitumor promoter from Moringa oleifera. Lam Mutat Res. , 440: 181-188.

Johnson E.H., Kass P.H. and Rosa S. (1995). Effects of energy supplementation and season on serum immunoglobulin and protein levels in Moxoto goats. Small Rumin Res., 15: 121-125.

Klasing, K.C.and Leshchincky, T.V (2000). Interactions between nutrition and immunity: Lesson from animal agriculture. In: Nutrition and immunology: principles and practices. M.E.Gersulin, S.B.German and C.L.Keen Eds. Humana press, Totowa, USA, chap.30, 363-374.

Makkar, H.P.S. and Becker, K. (1996). Nutritional value and antinutritional components of whole and ethanol extracted Moringa oleifera leaves. Ani. Feed Sci. Technol., 63: 211-228.

Mehta, L.K., Balaraman, R., Amin, A.H., Bafna P.A. and Gulati, O. D. (2003). Effect of fruits of Moringa oleifera on lipid profile of normal and hypercholesterolaemic rabbits. J. Ethnopharmacol., 86: 191-195.

Moscati L., Beghelli D., Valbonesi M., Sensi M., Mangili P.M., Marchi S., and Battistacci L. (2005). Effetti della somministrazione parenterale di slenio e vitamina $E$ su alcuni parametri dell'immunità aspecifica e stato ossidativi in bovine di razza chinina. In Proc.: 4th World Italian Beef Cattle Congress, 403-406. 
Moscati L., Dal Bosco A., Battistacci L., Cardinali R., Mugnai C., Castellini C. Mutayoba S. K., Dierenfeld E., Mercedes V. A., Frances Y., Knight C. D. (2008). Native immunity and oxidative traits of growing rabbits. World Rabbit Sci., 16: 213 - 220.

Moyo, B., Oyedemi, S., Masika, P.J. and Muchenje, V. (2012). Polyphenolic content and antioxidant properties of Moringa oleifera leaf extracts and enzymatic activity of liver from goats supplemented with Moringa oleifera leaves/ sunflower seed cake. Meat Science, 91, 441-447.

NRC, National Research Council (1977). Nutrient Requirements of Domestic Animal. USA National Academy of Science. Washington, D.C.

Okorie, K.C. (2003). The Effect of palmitic acidfortified maize wet milling by-product on the performance of weaner rabbits. Czech. J. Anim Sci, 48(9): 365-370.

Olugbemi, T.S., Mutayoba, S.K. and Lekule, F.P. (2010). Effect of Moringa (Moringa oleifera) inclusion in cassava based diets fed to broiler chickens. Internat. J. of Poult. Sci., 9: 363-367.

Ritu, P.; Veena, S. and Pracheta, S. (2011). A Review on Horse Radish Tree (Moringa oleifera): A Multipurpose Tree with High Economic and Commercial Importance. Asian J. Biotechnology, 3: 317-328.

SAS (2004). Statistical Analysis System User's Guide. Release 9.1. SAS institute, Cary, North Carolina.

Soetan, K.O.; Akinrinde, A.S. and Ajibade, T.O. (2013). Preliminary studies on the haematological parameters of cockerels fed raw and processed guinea corn (Sorghum bicolor). Proceedings of $38^{\text {th }}$ Annual Conference of Nigerian Society for Animal Production, pp: 49-52.

Sudha, P.; Asdaq, S.M.; Dhamingi, S.S. and Chandrakala, G.K. (2010). Immunomodulatory activity of methanolic extract of Moringa oleifera in animals. Ind. J. Physiol. Pharmacol., 54: 133-140.

Sonnerwirth, A.C. and Jarrett, L.D. (1980). Gradwal's (Clinical Llaboratory Methods and Diagnosis). Vol. $18^{\text {th }}$ Ed. Pp. 258-259. The C.V Mosby Co, ST, Louis, Toronto, London.

Suarez, M., Haenni, M., Canarelli, S., Fisch, F., Chodanowski, P., Servis, C., Michelin, O., Frietag, R., MoreillonP. and Mermod, N. (2005). Structure-Function characterization and optimization of a plant-derived antibacterial peptide. Antibacterial Agents Chemotherapy, 49: 3847-3857. 
Tizard I.R. (2013). Veterinary Immunology, $9^{\text {th }}$ edition. Elsevier Saunders, St. Louis, MO, USA.

Valeria, V. and Williams, P. (2011). Improving meat quality through natural antioxidants. Chilean J. Agric. Res., 71: 2.

Yassmin M. El-Gindy; Zeweil, H.S. and Hamad, M. (2017). Effects of moringa leaf as a natural antioxidant on growth performance, blood lipid profiles and immune response of rabbits under moderat heat stress. Egypt. Poult. Sci., Vol. (37) (II): 333-344.

\section{تأثير إضافة مسحوق أوراق المورينجا ( مورينجا أوليفيرا) الجافة في الأفي الإني

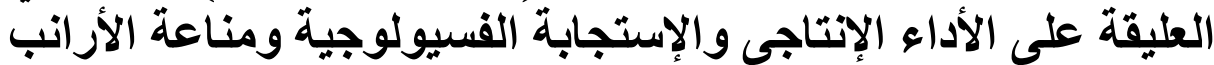 النامية}

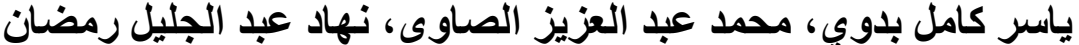

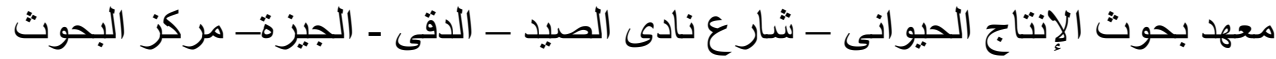

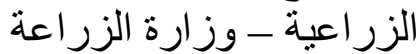

إستخدم فى هذه التجربة عدد 454 أرنب نيوزيلندي ابيض عمر خمسة أسابيع

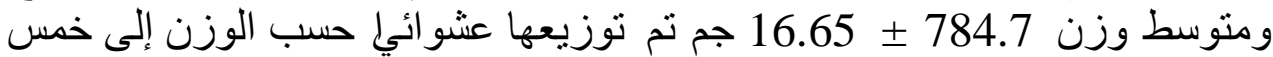

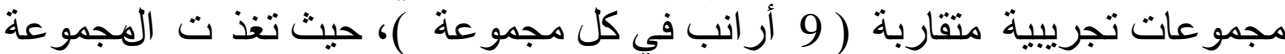

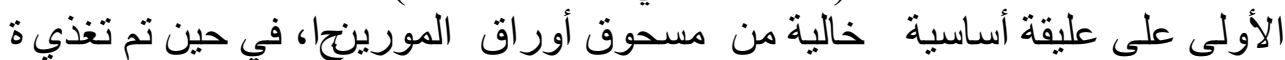

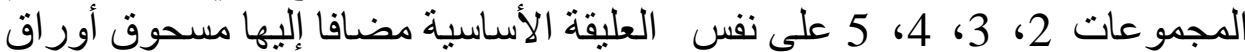

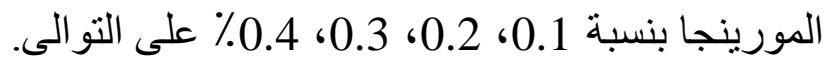

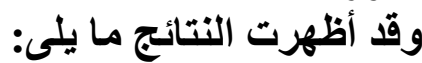

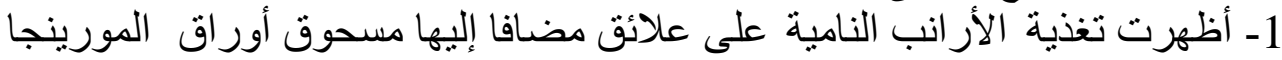

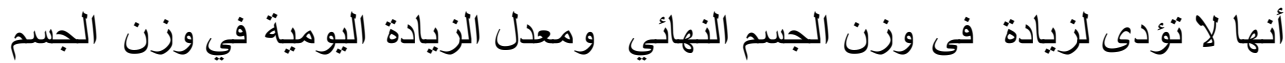

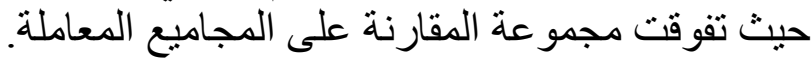

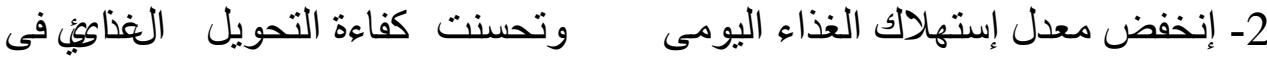

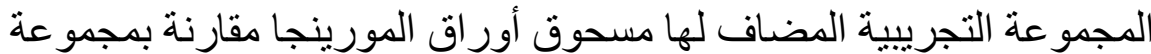
الكنترول وكانت الفروق معنوية على مستوى معنوية 0.05

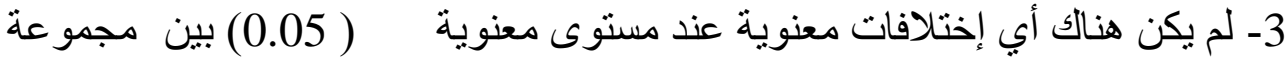

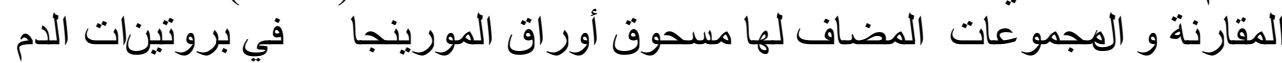

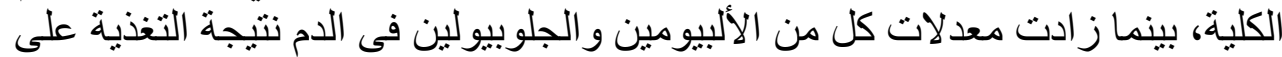


مسحوق أور اق المورينجا مما يعكس تحسن الحالة الفسيولوجية و المناعية للأر انب المعاملة بالمورينجا. 4- إرتفع الليسوزيم بشكل كبير جدا في سيرم دم الأرانب المعاملة بمستويات مختلفه من المورينجا مقارنة بالكنترول.

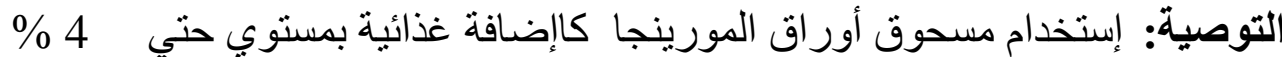

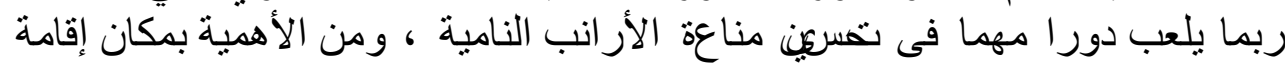

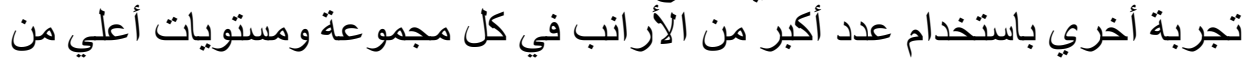

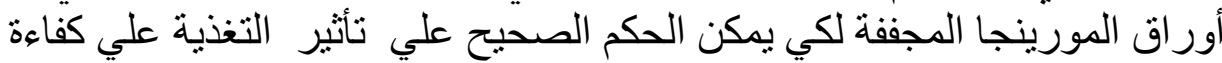
أداء الأر انب و الإستجابة المناعية و الحالة الصحية للأر انب. 